\title{
E3 ubiquitin ligase components in GtoPdb v.2021.3
}

\author{
Elena Faccenda ${ }^{1}$ and Robert Layfield ${ }^{2}$
}

1. University of Edinburgh, UK

2. The University of Nottingham, UK

\begin{abstract}
Ubiquitination (a.k.a. ubiquitylation) is a protein post-translational modification that typically requires the sequential action of three enzymes: E1 (ubiquitin-activating enzymes), E2 (ubiquitinconjugating enzymes), and E3 (ubiquitin ligases) [19]. Ubiquitination of proteins can target them for proteasomal degradation, or modulate cellular processes including cell cycle progression, transcriptional regulation, DNA repair and signal transduction.

E3 ubiquitin ligases, of which there are $>600$ in humans, are a family of highly heterogeneous proteins and protein complexes that recruit ubiquitin-loaded E2 enzymes to mediate transfer of the ubiquitin molecule from the E2 to protein substrates. Target substrate specificity is determined by a substrate recognition subunit within the E3 complex.
\end{abstract}

\section{Contents}

This is a citation summary for E3 ubiquitin ligase components in the Guide to Pharmacology database (GtoPdb). It exists purely as an adjunct to the database to facilitate the recognition of citations to and from the database by citation analyzers. Readers will almost certainly want to visit the relevant sections of the database which are given here under database links.

GtoPdb is an expert-driven guide to pharmacological targets and the substances that act on them. GtoPdb is a reference work which is most usefully represented as an on-line database. As in any publication this work should be appropriately cited, and the papers it cites should also be recognized. This document provides a citation for the relevant parts of the database, and also provides a reference list for the research cited by those parts. For further details see [2].

Please note that the database version for the citations given in GtoPdb are to the most recent preceding version in which the family or its subfamilies and targets were substantially changed. The links below are to the current version. If you need to consult the cited version, rather than the most recent version, please contact the GtoPdb curators.

\section{Database links}

E3 ubiquitin ligase components

https://www.guidetopharmacology.org/GRAC/FamilyDisplayForward?familyId=1023

Enzymes

cereblon

https://www.guidetopharmacology.org/GRAC/ObjectDisplayForward?objectId=3086

MDM2 proto-oncogene

https://www.guidetopharmacology.org/GRAC/ObjectDisplayForward?objectId=3136

\section{References}

1. Asatsuma-Okumura T, Ito $\mathrm{T}$ and Handa H. (2019) Molecular mechanisms of cereblon-based drugs. Pharmacol Ther 202: 132-139 [PMID:31202702]

2. Buneman P, Christie G, Davies JA, Dimitrellou R, Harding SD, Pawson AJ, Sharman JL and Wu Y. (2020) Why data citation isn't working, and what to do about it Database 2020

[PMID:32367113]

3. Carvajal LA, Neriah DB, Senecal A, Benard L, Thiruthuvanathan V, Yatsenko T, Narayanagari SR, Wheat JC, Todorova TI and Mitchell K et al.. (2018) Dual inhibition of MDMX and MDM2 as 
a therapeutic strategy in leukemia. Sci Transl Med 10 [PMID:29643228]

4. Chamberlain PP, Lopez-Girona A, Miller K, Carmel G, Pagarigan B, Chie-Leon B, Rychak E, Corral LG, Ren YJ and Wang M et al.. (2014) Structure of the human Cereblon-DDB1lenalidomide complex reveals basis for responsiveness to thalidomide analogs. Nat Struct Mol Biol 21: 803-9 [PMID:25108355]

5. Del Prete D, Rice RC, Rajadhyaksha AM and D'Adamio L. (2016) Amyloid Precursor Protein (APP) May Act as a Substrate and a Recognition Unit for CRL4CRBN and Stub1 E3 Ligases Facilitating Ubiquitination of Proteins Involved in Presynaptic Functions and Neurodegeneration. J Biol Chem 291: 17209-27 [PMID:27325702]

6. Fischer ES, Böhm K, Lydeard JR, Yang H, Stadler MB, Cavadini S, Nagel J, Serluca F, Acker V and Lingaraju GM et al.. (2014) Structure of the DDB1-CRBN E3 ubiquitin ligase in complex with thalidomide. Nature 512: 49-53 [PMID:25043012]

7. Gandhi A, Dimartino J and Chopra R. (2014) Methods for the treatment of locally advanced breast cancer Patent number: WO2014039960A1.

8. Gandhi AK, Kang J, Havens CG, Conklin T, Ning Y, Wu L, Ito T, Ando H, Waldman MF and Thakurta A et al.. (2014) Immunomodulatory agents lenalidomide and pomalidomide costimulate $\mathrm{T}$ cells by inducing degradation of $\mathrm{T}$ cell repressors Ikaros and Aiolos via modulation of the E3 ubiquitin ligase complex CRL4(CRBN.). Br J Haematol 164: 811-21 [PMID:24328678]

9. Hagner PR, Man HW, Fontanillo C, Wang M, Couto S, Breider M, Bjorklund C, Havens CG, Lu G and Rychak E et al.. (2015) CC-122, a pleiotropic pathway modifier, mimics an interferon response and has antitumor activity in DLBCL. Blood 126: 779-89 [PMID:26002965]

10. Hartmann MD, Boichenko I, Coles M, Zanini F, Lupas AN and Hernandez Alvarez B. (2014) Thalidomide mimics uridine binding to an aromatic cage in cereblon. J Struct Biol 188: 225-32 [PMID:25448889]

11. Heim C, Pliatsika D, Mousavizadeh F, Bär K, Hernandez Alvarez B, Giannis A and Hartmann MD. (2019) De-Novo Design of Cereblon (CRBN) Effectors Guided by Natural Hydrolysis Products of Thalidomide Derivatives. J Med Chem 62: 6615-6629 [PMID:31251063]

12. Higgins JJ, Hao J, Kosofsky BE and Rajadhyaksha AM. (2008) Dysregulation of largeconductance $\mathrm{Ca} 2+$-activated $\mathrm{K}+$ channel expression in nonsyndromal mental retardation due to a cereblon p.R419X mutation. Neurogenetics 9: 219-23 [PMID:18414909]

13. Higgins JJ, Pucilowska J, Lombardi RQ and Rooney JP. (2004) A mutation in a novel ATPdependent Lon protease gene in a kindred with mild mental retardation. Neurology 63: 1927-31 [PMID:15557513]

14. Ito T, Ando H, Suzuki T, Ogura T, Hotta K, Imamura Y, Yamaguchi Y and Handa H. (2010) Identification of a primary target of thalidomide teratogenicity. Science 327: 1345-50 [PMID:20223979]

15. Ito T and Handa H. (2016) Cereblon and its downstream substrates as molecular targets of immunomodulatory drugs. Int J Hematol 104: 293-9 [PMID:27460676]

16. Lopez-Girona A, Mendy D, Ito T, Miller K, Gandhi AK, Kang J, Karasawa S, Carmel G, Jackson P and Abbasian $\mathrm{M}$ et al.. (2012) Cereblon is a direct protein target for immunomodulatory and antiproliferative activities of lenalidomide and pomalidomide. Leukemia 26: 2326-35 [PMID:22552008]

17. Matyskiela ME, Zhang W, Man HW, Muller G, Khambatta G, Baculi F, Hickman M, LeBrun L, Pagarigan B and Carmel G et al.. (2018) A Cereblon Modulator (CC-220) with Improved Degradation of Ikaros and Aiolos. J Med Chem 61: 535-542 [PMID:28425720]

18. Momand J, Zambetti GP, Olson DC, George D and Levine AJ. (1992) The mdm-2 oncogene product forms a complex with the p53 protein and inhibits p53-mediated transactivation. Cell 69: 1237-45 [PMID:1535557]

19. Morreale FE and Walden H. (2016) Types of Ubiquitin Ligases. Cell 165: 248-248.e1 [PMID:27015313]

20. Nabet B, Roberts JM, Buckley DL, Paulk J, Dastjerdi S, Yang A, Leggett AL, Erb MA, Lawlor MA and Souza A et al.. (2018) The dTAG system for immediate and target-specific protein degradation. Nat Chem Biol 14: 431-441 [PMID:29581585]

21. Ng SY, Yoshida N, Christie AL, Ghandi M, Dharia NV, Dempster J, Murakami M, Shigemori K, Morrow SN and Van Scoyk A et al.. (2018) Targetable vulnerabilities in T- and NK-cell lymphomas identified through preclinical models. Nat Commun 9: 2024 [PMID:29789628]

22. Nguyen TV, Lee JE, Sweredoski MJ, Yang SJ, Jeon SJ, Harrison JS, Yim JH, Lee SG, Handa H and Kuhlman B et al.. (2016) Glutamine Triggers Acetylation-Dependent Degradation of Glutamine Synthetase via the Thalidomide Receptor Cereblon. Mol Cell 61: 809-20 [PMID:26990986]

23. Pairawan S, Zhao M, Yuca E, Annis A, Evans K, Sutton D, Carvajal L, Ren JG, Santiago S and Guerlavais V et al.. (2021) First in class dual MDM2/MDMX inhibitor ALRN-6924 enhances antitumor efficacy of chemotherapy in TP53 wild-type hormone receptor-positive breast cancer models. Breast Cancer Res 23: 29 [PMID:33663585]

24. Remillard D, Buckley DL, Paulk J, Brien GL, Sonnett M, Seo HS, Dastjerdi S, Wühr M, DhePaganon S and Armstrong SA et al.. (2017) Degradation of the BAF Complex Factor BRD9 by 
Heterobifunctional Ligands. Angew Chem Int Ed Engl 56: 5738-5743 [PMID:28418626]

25. Ries S, Biederer C, Woods D, Shifman O, Shirasawa S, Sasazuki T, McMahon M, Oren M and McCormick F. (2000) Opposing effects of Ras on p53: transcriptional activation of mdm2 and induction of p19ARF. Cell 103: 321-30 [PMID:11057904]

26. Sasaki M, Kawahara K, Nishio M, Mimori K, Kogo R, Hamada K, Itoh B, Wang J, Komatsu Y and Yang YR et al.. (2011) Regulation of the MDM2-P53 pathway and tumor growth by PICT1 via nucleolar RPL11. Nat Med 17: 944-51 [PMID:21804542]

27. Sheereen A, Alaamery M, Bawazeer S, Al Yafee Y, Massadeh S and Eyaid W. (2017) A missense mutation in the $C R B N$ gene that segregates with intellectual disability and self-mutilating behaviour in a consanguineous Saudi family. J Med Genet 54: 236-240 [PMID:28143899]

28. Sun D, Li Z, Rew Y, Gribble M, Bartberger MD, Beck HP, Canon J, Chen A, Chen X and Chow D et al.. (2014) Discovery of AMG 232, a potent, selective, and orally bioavailable MDM2-p53 inhibitor in clinical development. J Med Chem 57: 1454-72 [PMID:24456472]

29. Vu B, Wovkulich P, Pizzolato G, Lovey A, Ding Q, Jiang N, Liu JJ, Zhao C, Glenn K and Wen Y et al.. (2013) Discovery of RG7112: A Small-Molecule MDM2 Inhibitor in Clinical Development. ACS Med Chem Lett 4: 466-9 [PMID:24900694] 